\title{
Full article \\ The global reality of the Paralympic Movement: Challenges and opportunities in disability sports
}

\author{
Eliane Mauerberg-deCastro \\ Debra Frances Campbell \\ Universidade Estadual Paulista “Júlio de Mesquita Filho,” Rio Claro, SP, Brasil \\ Carolina Paioli Tavares \\ Universidade Estadual de Ponta Grossa, Ponta Grossa, PR, Brasil
}

\begin{abstract}
The purpose of this study was to briefly illustrate some of the challenges and realities of national and international Paralympic sports. The elite disabled athlete paradigm is still not widely known in the world of regular sports competitions. The winning elite disabled athletes are restricted to a few countries, including the U.S., Canada, Germany, China, and Australia, with limited distribution of disability sport opportunities in other countries. This tendency for the success of a minority of countries reflects global problems of social vulnerability in accessibility (e.g., in dismantling the stigma of disability), political vulnerability (e.g., representative organizations of sports for the disabled do not fully pratice the philosophy of "sport for all"), and economic vulnerability (e.g., lack of opportunities for training, assistive sports technology, and sponsorships). Furthermore, elite Paralympic athletes have become veterans. For example, the participation of Brazilian elite athletes in the 1984 Paralympics marked the beginning of a new generation of athletes (approximately 16\%) who returned to the Games in 1988. In both 2008 and 2012, nearly 28\% of total participants were Brazilian veterans. Although this picture reveals longevity of athletes in the sport, there are many limitations in sports accessibility, often due to geographical centralization of opportunities in large urban centers. Yet, today, the world of Paralympic sport has been transformed into a sports spectacle, thanks to the exceptional performance of some athletes, to the technology of mass communication, and to the support of audiences during the Games. These sport "superstars" offer the world new images and new constructs of "ability." While this forum has helped to bring attention to these "heroes," other Brazilian athletes (and from other countries as well) are still waiting for their opportunities. Indeed, worldwide, young blind individuals, those in wheelchairs, amputees, or simply the uncoordinated, expect to play, run, swim, and take part in the international model of "sport for all." They expect sports opportunities to be a part of their daily lives, an option for rehabilitation and the preservation of health, and a basic human right.
\end{abstract}

Keywords: Paralympic games, disability sports, Paralympic Movement

\section{Introduction}

Since the 1940s, people with disabilities have been using sport as a therapeutic tool to overcome health complications, prevent secondary disabilities, and to survive. Experiences with survival include preventing premature death and dealing with society's stigma. These experiences also have helped athletes with disabilities construct a new dimension in the paradigm of "overcoming limits in sports"1,3. However, across cultures around the world, elite athletes with disability have a common reality that includes restricted access to assistive technology and specific sports equipment, limited media coverage and lack of sponsorships, ethical issues and doping, sports injuries, and provisions for retirement, among others. Also, their voices are often silent and are seldom part of the decision-making process in sports organizations. The diversity of competencies required for effective leadership in sports organizations and a traditional "medical model" approach in many nations toward disability pose the risk that the disability sports environment will continue to be patronizing ${ }^{4}$. Such patronizing attitudes typically lead to segregation $^{4,5}$.

Worldwide organizations have attempted to be sensitive to issues of segregation in order to protect human rights. Leading international human rights organizations, such as the World Programme of Action Concerning Disabled Persons, for example, have endorsed practices of inclusion of individuals with disability in the arena of sports, in particular during school activities ${ }^{6}$. However, many countries and societies around the world have not completely abandoned the institutional model in education ${ }^{4,7,8}$. Therefore, in such countries the presence of students and athletes with disability in inclusive settings is rare. Even rarer is the presence of teachers and coaches with disability, whether in an initiation or high-performance setting. As a result, athletes with disability tend to be alienated with respect gaining knowledge and opportunities related to becoming professionals in the business of sport.

Over the past several decades the Paralympic games as a global event, and the International Paralympic Committee (IPC) 
as a global organization, helped to create forums for popularizing disability sports ${ }^{[1]}$ among the general population. Using mass and social media, and employing advocacy strategies for human rights and inclusion, as well as international campaigns for health promotion through sports, IPC has helped to expand the ordinary sports viewer's notions of sports performance and entertainment. This, in turn, has helped to empower people with disability in the role of athlete, coach, administrator, and business person, even though the IPC is a non-profit entity, as are many other disability sports organizations.

In addition to promoting sports excellence, the IPC's strategic plan 2015-2018 includes vital issues that need to be addressed to guarantee the success of the Paralympic Movement, as well as to detect potential problems areas ${ }^{9}$. These include fostering representation and liaison by people with disability and institutional partners (e.g., the United Nations); democratic access to sports by all (e.g., the Agitos program); economic challenges in various world regions (e.g., branding sports and sustainable funding); fame, ethics, and doping; health and sports injuries; and retirement and sports career transitions.

Our purpose here is to summarize major accomplishments in the history of the Paralympic Movement — both successes and shortcomings. Also, we hope to provide an overview of some of the issues that inspire the IPC's current strategic plan, and to contextualize these, in particular with regard to the Brazilian Paralympian Movement.

\section{From survival to high performance: The winners and the legacy}

Engagement of disabled people in sport activities is commonly acknowledged as a vital protocol in their rehabilitation. Health professionals have become accustomed to using sport as a key therapeutic tool for rehabilitation, for the prevention of health problems, and to reduce the rate of mortality.

Disability sports emerged with the return home of casualties from First and Second World Wars ${ }^{[2]}$. Practice of physical exercise was officially identified in hospitals in North America and Europe in the early $20^{\text {th }}$ century, primarily as a division of physical medicine and rehabilitation ${ }^{10}$. However, the sports paradigm in medical rehabilitation inside of hospitals was inspired by the neurologist, Dr. Ludwig Guttmann, who in 1944 developed a competitive "dressing exercise," known as Ward X, within the facilities of the Stoke Mandeville Hospital in Buckinghamshire, England ${ }^{11}$. Four years later, coinciding with the opening day of the Olympic Games in London, an archery competition took place in the hospital. In 1950, this event marked the creation of the Stoke Mandeville Festival of Sport. In 1952, these games became international in scope and a hallmark for the future Paralympic Games, which began in 1960 , in Rome.

For individuals who become disabled, engaging in sports can be a strategy for post-hospital survival. Disability sports help participants create defenses against the effects of secondary disabilities or health impairments (e.g., atrophy, infections, osteoporosis, significant orthopedic disorders), more common in these patients than in the general population ${ }^{5}$. Also, engaging in sports can provide opportunities for people with disabilities to experience a sense of empowerment, and to achieve excellence in sport performance.

Accustomed to extreme challenges, today's Paralympic athletes often exhibit spectacular performances of sporting ability, making the Paralympic Games the second largest sports event in the world (Figure 1), and an extraordinary phenomenon of diversity. However, the elite disability sport paradigm is still unknown in the world of regular sport competition, and the tradition of participation in elite disability sport is still reserved for a few disabled athletes and, for decades, to a few countries. In fact, it wasn't until after the early 1990s that more than half of the world's countries began participating in the Paralympic Games. In 2012, 84\% of countries worldwide attended the event, in contrast with 1960 , when only $12 \%$ of the world's countries were represented at the Games. Advances in sport science, training, assistive technology, and modernization of the functional classification system ${ }^{[3]}$ that replaced the medical model,

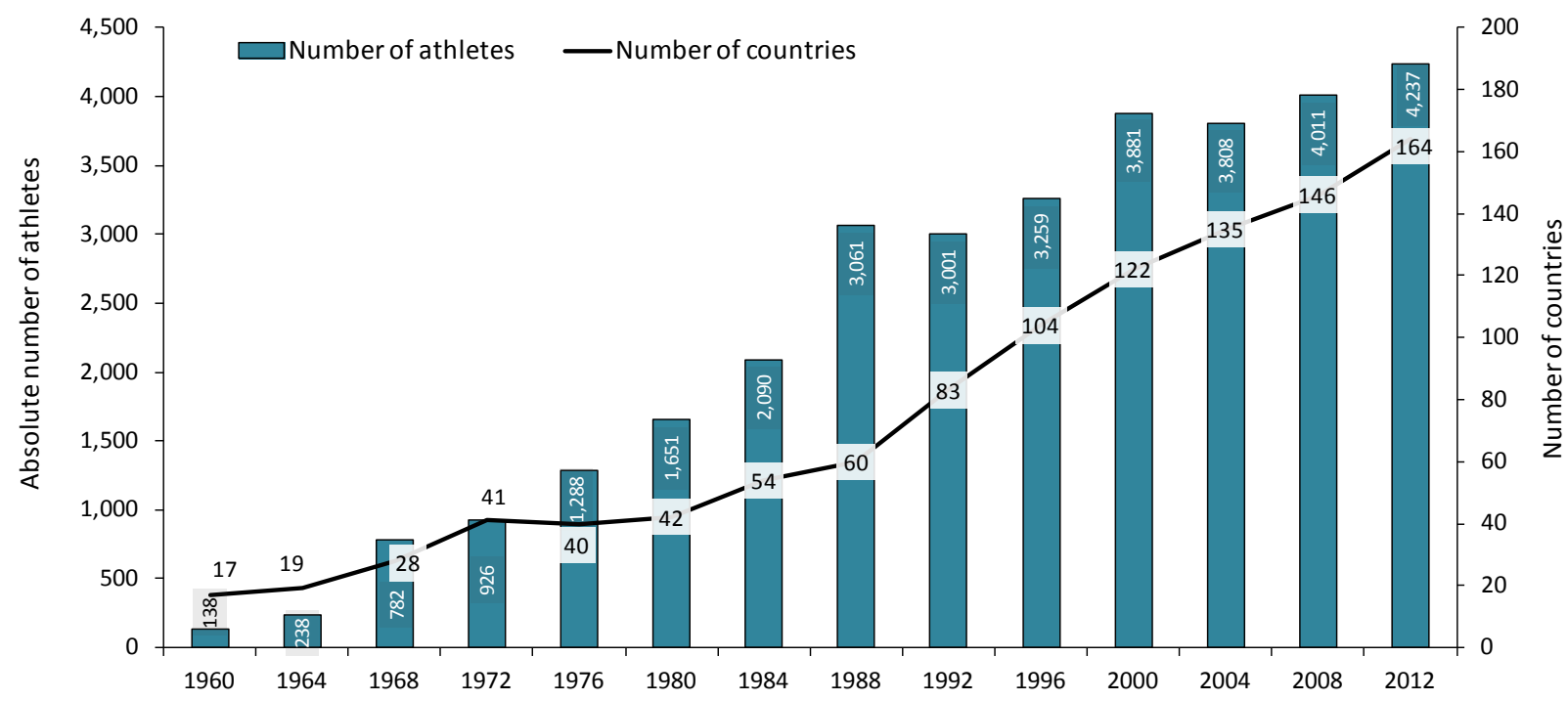

Figure 1. Global participation (athletes and countries) in the Paralympic Games, from 1960 until $2012^{9}$. 
all have increased the volume of participants globally, although the number of winning nations continues to be relatively small.

Winning results for disabled elite disabled athletes are still restricted to a few countries such as the U.S., Canada, Germany, China, and Australia, who have received between $9 \%$ and $29 \%$ of all medals, in all Paralympic Games. Brazil won $2.8 \%$ of the Paralympic sports medals in its best campaign in London ( $7^{\text {th }}$ place), in 2012, against first-ranked China's $15.2 \%$. The U.S. has attended all of the events since 1960, and has won First Place in eight out of a total of 16 Games over the past 52 years. The total amount of medals throughout the U.S.'s history of participation is 2,066 , from a total of 18,877
(11\%). China has the next best performance. Since its first participation in 1984, China has ranked First Place three times, with a total of 783 medals ( $5 \%$ of total medals from 1984 to 2012). Brazil has accumulated 228 medals since 1972 (1.3\% of all medals). Figure 2 shows the number of countries that have collected the majority of medals in contrast with countries that have won less than five medals. The success of the winning countries (an average of seven countries, with a minimum of two medals and a maximum of 14) reflects the earnings of an average of 818 medals (nearly $61 \%$ of the total medals awarded since 1960). Between 1972 and 1984, the number of participating countries has been stable, but with a very rapid and linear increase in number of medals, even though the top

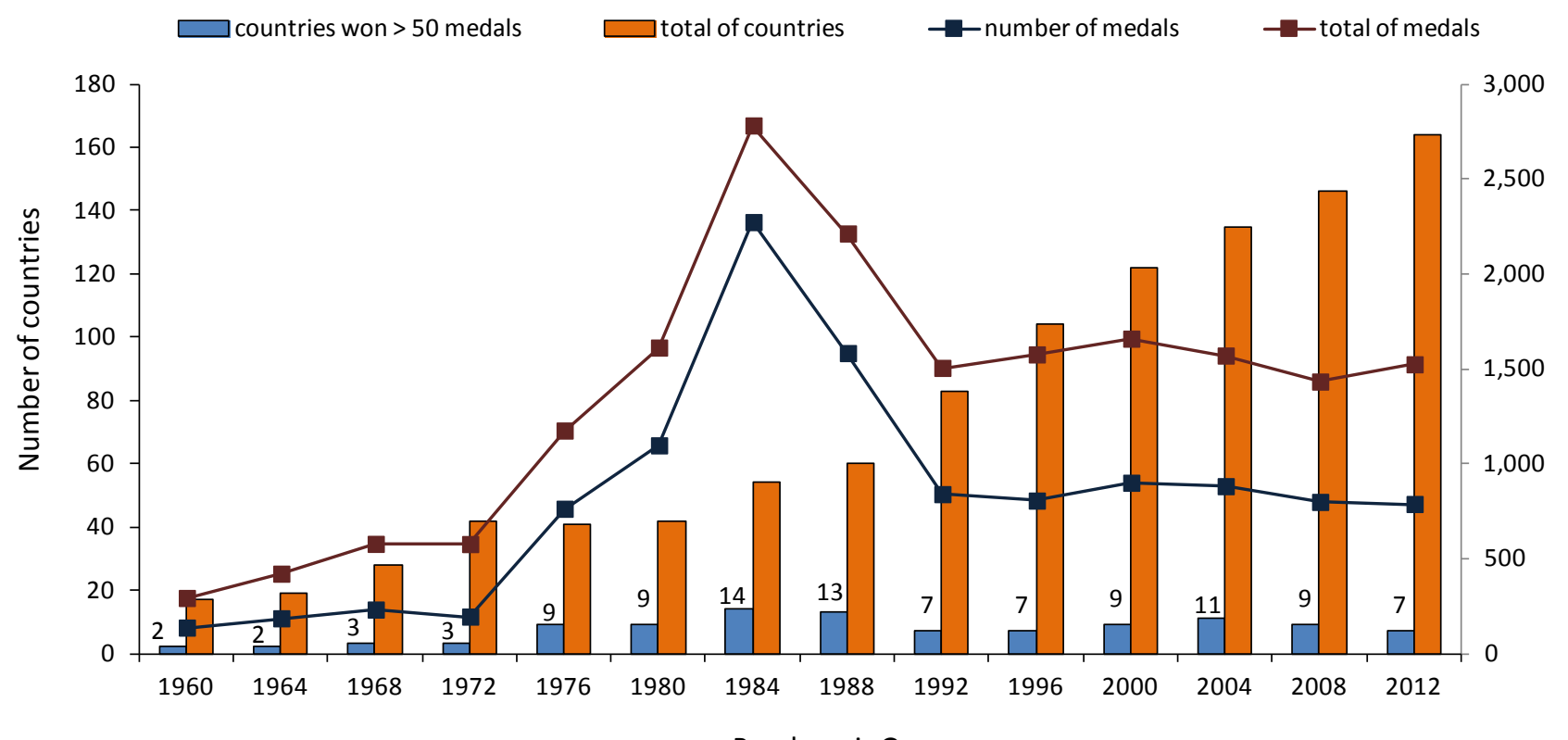

Paralympic Games

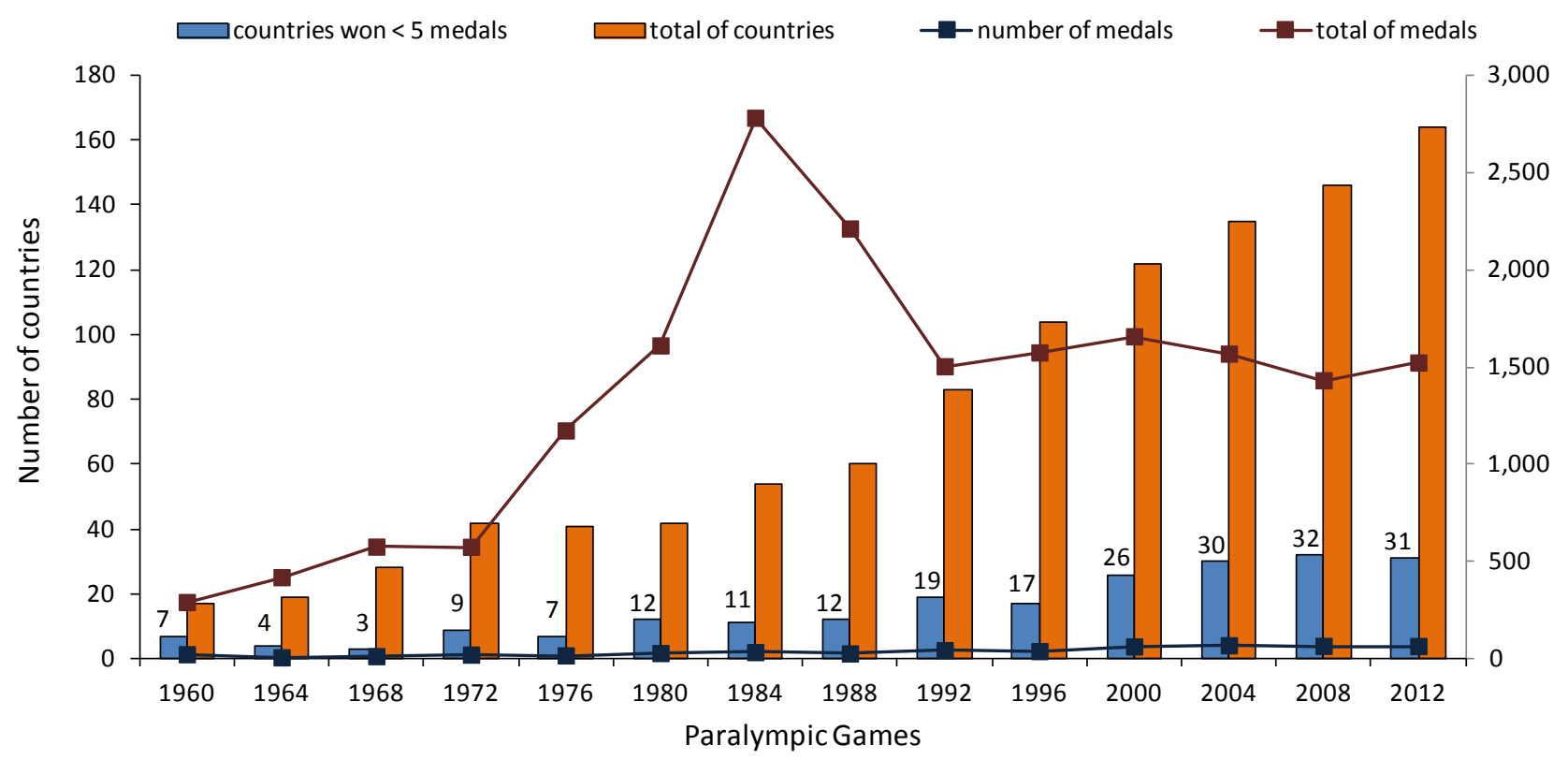

Figure 2. Total number of medals, and countries that have participated in the Paralympic Games since 1960. Contrast between the number of countries that have won more than 50 medals (top), and the countries that have won less than five medals (bottom) ${ }^{9}$. 
winners continue to come from only a relative few countries (e.g., Italy, U.S., Germany, Australia, and China). In 1992, the number of medals declined nearly by half.

Restrictions on the number of modalities by the IPC (currently 25 for summer events, and six for winter events) have limited the number of available medals. Insertions of sports are assessed by the IPC based on worldwide participation (i.e., countries and continents), quadrennial competition agenda, compliance with an athlete classification system, anti-doping program, rules and regulations, and evidences of sport attractiveness to audiences ${ }^{12}$. The other factor for limiting number of medals was the improvement of a functional classification system (i.e., the system determines the functional potential of athletic performance) - in opposition to the medical classification system (i.e., assessment of disability limitations in each sport class) —which was first used in 1992. These factors have been the most instrumental in stabilizing the volume of medals.

The number of countries that have earned no medals since 1960 has increased with the number of participating countries. In the last edition of the games, the proportions started to level, after 1996, between winners of some medals and participants with no medals. In 2012, 54\% of the participating countries did not win any medals (Figure 3).

Officially, the International Olympic Committee (IOC) does not recognize the medal table method that ranks countries at the Olympic Games, as members believe this prompts injustice to smaller countries, along with presenting other philosophical issues related to the Olympic movement. However, the employment of countries' medal rankings is

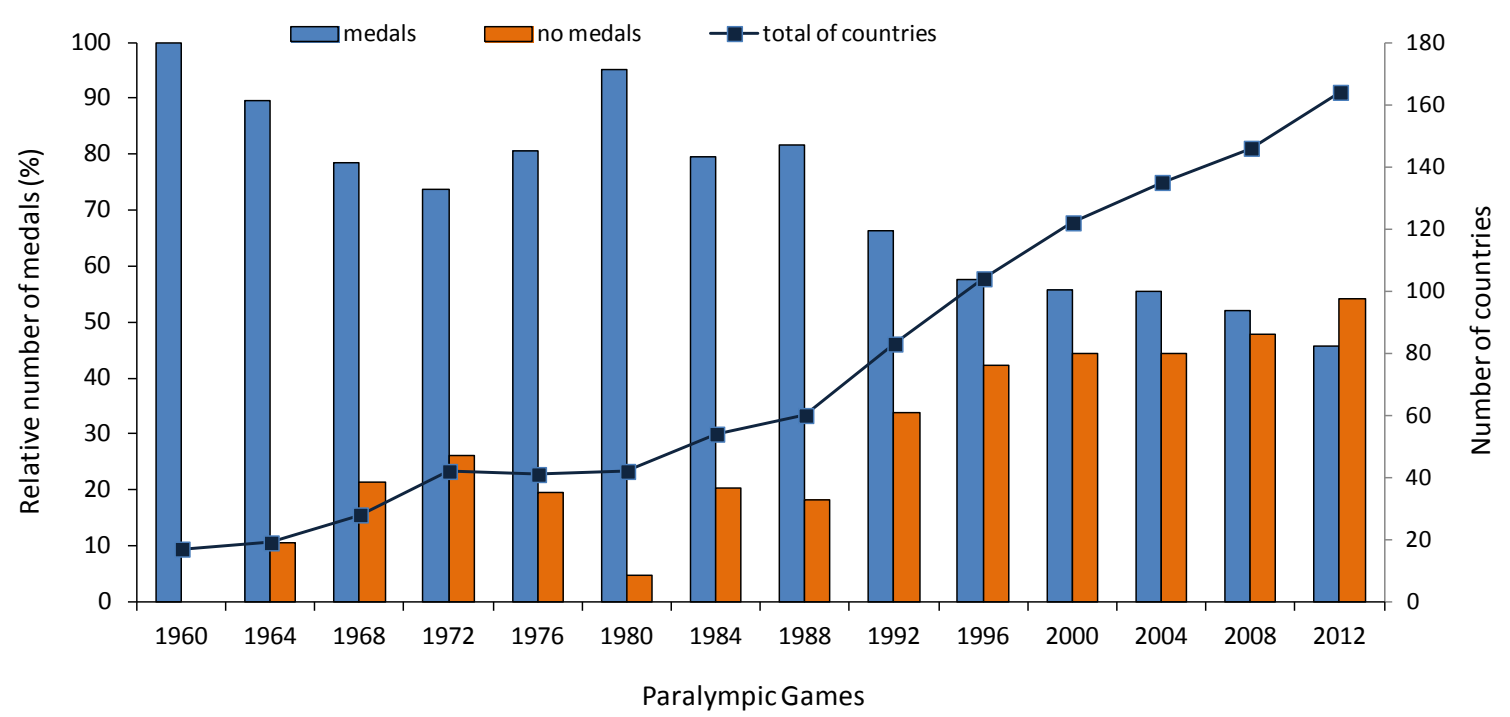

Figure 3. Contrast between countries that have participated in the Paralympic Games since 1960 that have won medals and countries that have won no medals 9 .

used here for the purpose of acquiring information about athletes' performances in the Games, some recorded as early as $1908^{13}$.

The discrepancy between the few winning countries and the remaining countries around the world reflects global problems of accessibility of people with disability to opportunities in sports. Many social structures in different societies around the world still struggle to dismantle the stigma of disability. Also, economic vulnerability affects a large number of countries, which results in lack of opportunities for training, poor or no assistive sports technology, the absence of professionals to integrate rehabilitation into the sports environment, as well as invisibility to sponsorship, among other factors ${ }^{14}$.

\section{The Brazilian scenario}

The Brazilian Paralympic scenario started in 1972, in Heidelberg (then West Germany), when, among the 40 participating countries, Brazil ranked in the $32^{\text {nd }}$ position. In the 2012 London Summer Paralympic Games, Brazil had climbed to seventh position among the 164 participating nations. Extraordinary results such as those achieved by swimmer Daniel Dias, who won six Gold medals and broke five world records, brings a sharp contrast with performances by nondisabled Brazilian Olympic athletes. He is considered the greatest Brazilian Paralympic medalist (15 medals in total $)^{15}$. Daniel paired his success with Alan Fonteles, double amputee (class T44), who completed the "100 meter" in 10.75 seconds, and the "200 meter" in 21.45 seconds. These results are not far from those of non-disabled athlete Usain Bolt during the 2012 Olympic Games: 9.58 seconds in the "100 meter," and 19.19 seconds in the "200 meter"16.

It seems unrealistic to compare the performance of Olympic and Paralympic athletes, due in part to the number of classes in disability sport competitions. However, in its short history with the Paralympic Games, Brazil, for example, has been successful in raising its status in the general classification rank $\left(7^{\text {th }}\right.$ place in London $)$. In the most recent Olympic Games in London, Brazil received 17 medals and was ranked in $14^{\text {th }}$ place. Throughout the history of Brazil's participation in a total of 22 Olympic games, athletes have returned home with 125 medals (26 Gold, 35 Silver and 64 
Bronze medals), according to the Brazilian Olympic Committee ${ }^{17}$. On the other hand, throughout their 11 editions of Paralympic participation, Brazilian athletes have brought home a total of 237 medals $^{18}$. Figure 4 depicts the relationship between number of Brazilian athletes, earned medals, and classification positions throughout the Paralympic Games since 1972. After the Games in Greece, the number of Brazilian athletes who represented the country nearly doubled relative to those in previous Games. Note that the general classification rank has steadily approached those of the top countries since the 1996 Paralympic Games in Atlanta.

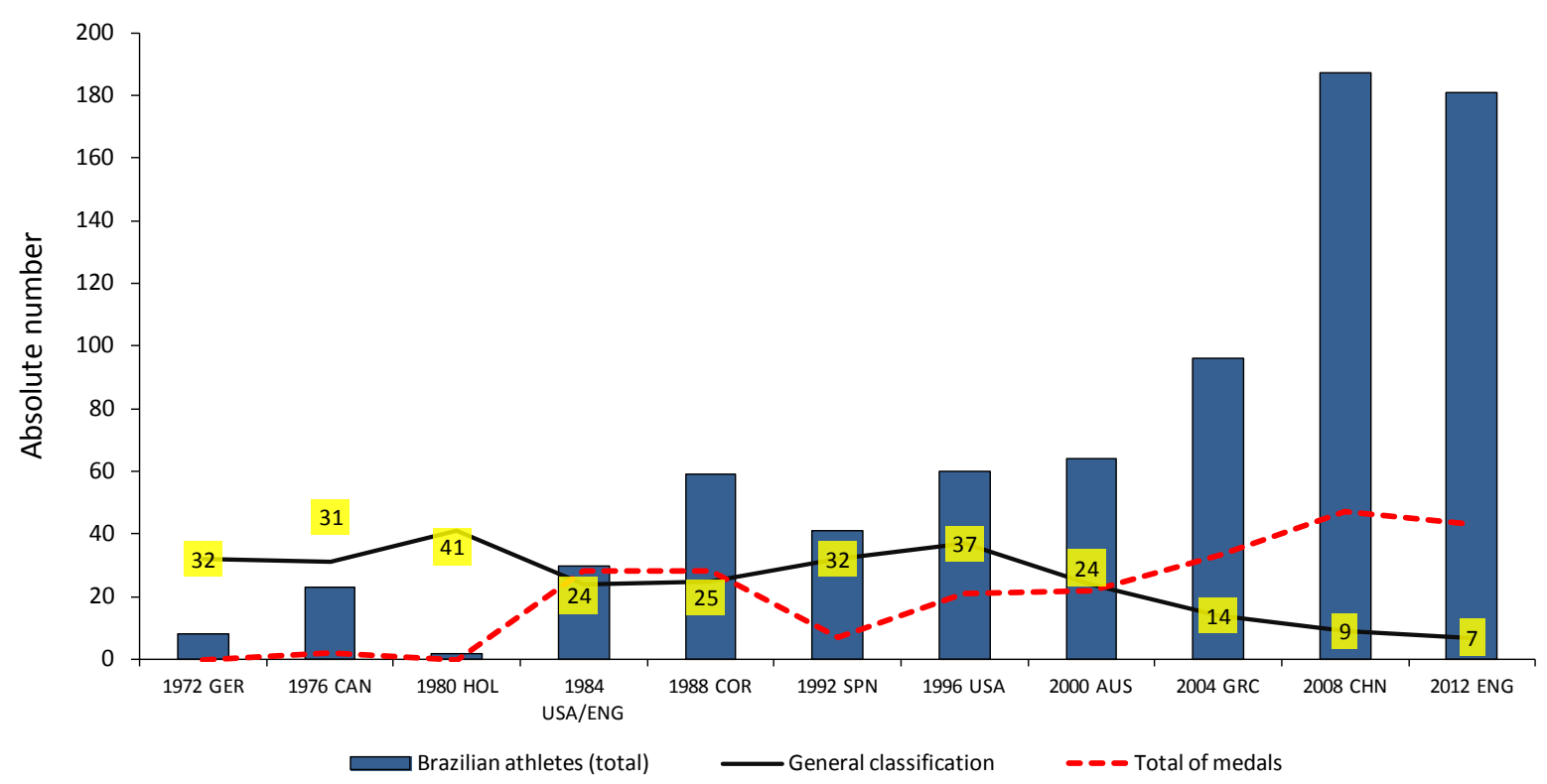

Figure 4. Absolute number of participant Brazilian athletes, earned medals, and general classification position in the Paralympic Games, from 1972 until 2012 (source: IPC, 2015a).

\section{Implementing and maintaining disability sports}

A major characteristic of disability sports is its association with rehabilitation. And, while exercise programs can help individuals with disability improve health and function, quite often these individuals seek social affiliation, personal affirmation, and self-empowerment through sports. Therefore, it is common to observe in athletes with disability a rapid climb to the elite sports in national and international scenarios. However, only limited opportunities for competitions exist, with a small number of eligible athletes for competitions as compared to those in regular sports, and only a very few of these reach the top or become elite athletes. Yet, the engagement of disabled athletes in national and international competitions may take as short as six months to two years from their start in the practice of sport, according to a review by Brazuna and Mauerberg-deCastro ${ }^{19}$. Therefore, athletes' rapid rise and longevity in the sport are two other dominant characteristics of disability sports.

Aware of how opportunities for healthy living could positively affect Chinese citizens with disability, in 2014, the Chinese Central Government implemented key projects to provide rehabilitation services throughout many regions of China. These projects now provide 7.5 million disabled individuals with ageand condition-appropriate, long-term specialized therapeutic protocols for all areas of disability and health challenges. Also, early detection of disability has become a part of these efforts, with rehabilitation integrated into sports. The national plan, supervised and administered by the China Disabled Persons' Federation (CDPF) and commissioned by the Government of China, attempts to cover wide areas of the lives of people with disability, including education, employment, sports, and rehabilitation. In 2014, the CDPF coordinated 800 sports events involving people with disability, and the training of 11,000 fitness coaches to work in disability sports. The number of provincial sports training bases now totals 234 countrywide. The CDPF serves as China's official National Paralympic Committee.

China, now a leading nation in the Paralympic Games, continuously invests in new developments in disability sports, and constantly reveals an extraordinary number of new elite athletes. Some countries like Brazil, however, continue to rely on a limited number of athletes who are members of a long-lasting, early generation of athletes. The elite Brazilian Paralympic athletes that have achieved success now are veterans. Of the 181 athletes who went to London in 2012, approximately $22 \%$ were athletes who had participated in previous Games, and $7 \%$ had participated in more than two Games. Although the 1984 Paralympics had fewer Brazilian athletes, their participation marked the beginning of a new generation of athletes $(16 \%)$ that returned to the next games. In 2008 and 2012, 24\% and 22\% respectively were Brazilian veteran athletes (Figure 5). Although this picture reveals longevity of athletes in the sport - which is unusual when compared to non-disabled athletes ${ }^{[4]}$, there are many limitations in sports accessibility, predominantly because of geographical centralization of opportunities in large urban centers. 


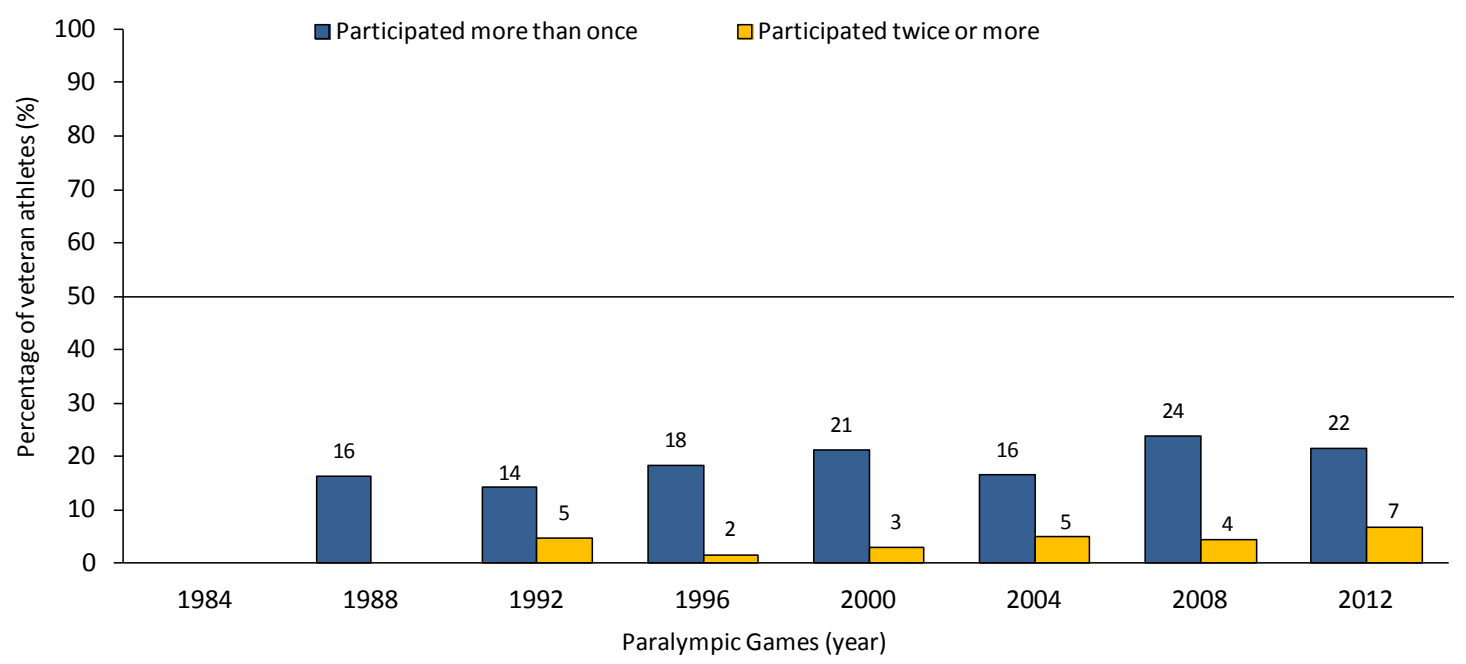

Figure 5. Veteran Brazilian Paralympic athletes returning more than once, and more than twice, to the Games. Participation from 1984 until 2012. (These data are subject to inaccuracies, as the precise number of athletes is unknown, especially in the early years of the Games. Some of the athletes' names were misspelled or omitted from the IPC database) $)^{9}$.

The Brazilian veteran athletes who participated in the Paralympic Games the most times are Ádria dos Santos and Antonio Tenório da Silva, at five times each, competing for 16 years at the Paralympic level since 1996. Typically, longevity of the athletic career is desirable - which also is true for non-disabled athletes. Yet, Brazil is a large country geographically, and athletes must congregate in large urban centers, where most training and sports practice opportunities are located. This requires many athletes to move from their hometowns to participate in training and to receive assistive care, as rehabilitation is part of the training protocol. The long-term commitment to moving away from families and friends, as well as to compliance with goals and training seasons, also depend on resources from sponsorships and government grants.

Government agencies in some societies, such as in Brazil, for example, show confusion about how to implement "sport for all," therefore setting disability sport within a marginalized, elitist, non-democratic context. Even many organizations whose goal is to represent sports for the disabled haven't yet successfully constructed a widespread tradition of implementing sports opportunities to individuals with disability. Outstanding sports programs are commonly located in large cities. Often, partnerships between universities and organizations/institutions interested in sports programs are vehicles through which people with disability find opportunities for practicing a sport. Since the number of universities is limited, and most opportunities happen within urban centers, many young (future) athletes with disability from other geographic locations will never explore such opportunities.

\section{Fame and achievements: Ethics (or lack of) in the Paralympic Movement}

Although "heroism" and "sportsman" are common descriptors granted to disabled athletes who become part of the elite cadre in the sport scenario, the world of Paralympic sports competition is not immune to scandal, corruption, and illicit means for achieving success. In fact, in Paralympic sports, the discussion of ethics involves an "ambiguity of expectations" related to the concepts of inclusion and accessibility. Santamaria and Mazzeo ${ }^{20}$ explored this ambiguity in relation to the prevalence of doping in sport. These authors observed that doping negatively affects the image of the sport industry and represents a serious threat to the health of the athlete. Yet, the act of winning increases the probability that an athlete will be rewarded with sponsorships, fame, and money. Therefore, many athletes are willing to take risks, even participating in unethical activities such as doping. Athletes with disabilities, too, are part of this problem.

In the 2000 Summer Paralympics, the Spanish basketball team, in the class of intellectual disabilities, was disqualified after winning the Gold medal. None of the athletes were intellectually disabled. The incident showed the fragility of the classification system and the weak eligibility criteria for athletes with intellectual disability. The result was the suspension of intellectual disability from the Paralympics, which returned only in 2012.

The Paralympic Games have been relatively free of scandal, but many disabled athletes have been caught violating the AntiDoping Code ${ }^{21}$. In 2015, the Portuguese Paralympic Committee launched its educational campaign about doping that targeted athletes with disabilities. With the intention to "promote and protect the integrity of sport and the health of athletes," the IPC, along with the international federations and national Paralympic committees, organized the IPC Anti-Doping Code ${ }^{22}$.

According to Van de Vliet $^{23}$, an incidence of only $1 \%$ of violations of the anti-doping rules in the Paralympic Movement has been reported. Violations usually are detected and recorded during competition. Since 2000, a total of 60 violations were registered by the International Paralympic Committee. Of these, 37 were detected in weightlifting, which is four times the incidence of any violation in the next sport modality, athletics.

Annually, since 2007, the IPC anti-doping test results are publicly exposed and, once investigation confirms an athlete's 
doping test failure, the IPC reveals the athlete's identity and reason for disqualification. In 2004, a Brazilian weightlifter was permanently banned for using methasterone metabolite ${ }^{22}$. The athlete's banning figures alongside two other athletes in this category of severity. The list of names of athletes who are currently serving limited bans to participate in the year 2015 includes at least 15 athletes from various countries.

The IPC 2007 statistical report of violations of the Doping Code from the sample of 288 athletes detected 15 violations ranging from "atypical results" to "confirmed violations." Statistics from the Beijing Games, including doping tests conducted outside of and during competitions, showed that the number of tested athletes increased to 1,155 , with 32 violations. Once a violation is detected, the process of an athlete's defense begins before the Committee makes a final decision. In 2011, a Brazilian weightlifter was suspended for two years for violating the Anti-Doping Code. Again in 2012, another Brazilian weightlifter was suspended for nine months. Weightlifting, as mentioned above, is among the sports whose athletes most often violate the anti-doping code. Of the sanctions for the seven total violations in 2010, four were for weightlifters. In 2011, the number was again four (out of seven) weightlifters. In 2012, for a total of eight penalties, six were given to weightlifters. In 2013, seven of the ten penalties went to weightlifters, and, in 2014 , eight of eleven penalties were given to weightlifters ${ }^{22}$.

Another problem is that, like many of today's athletes, Paralympic athletes use dietary supplements. Pipe and Ayotte ${ }^{24}$ claimed that contaminated nutritional supplements have a huge potential for resulting in positive doping tests, and this reality is one of the main concerns of coaches and athletes. Countless supplements available in the market are contaminated with steroids and stimulants that are prohibited by the Anti-Doping Code. Furthermore, athletes with disabilities often depend on the chronic use of medications associated with complications that arise from their health conditions. This situation obfuscates the work of the Anti-Doping Committee and creates the need for each athlete to update their biological profile with the IPC by a licensed physician.

Another controversial doping practice in the Paralympic world is called "boosting." This practice, performed by spinal cord-injured athletes with lesions above the $6^{\text {th }}$ vertebra, is the deliberate induction of chest pain or discomfort in the body areas below the lesion. The result, in addition to increased blood pressure in contrast to a low heart rate, is an improvement in circulation of the muscles. Boosting is the deliberate self-induction of autonomic dysreflexia, in which systolic blood pressure raises up to $180 \mathrm{mmHg}$ or above. The potential risk is a stroke, intracranial hemorrhage, and death. Despite this, some athletes run these risks, because they believe they can improve athletic performance by up to $15 \%$. Treated separately from other forms of doping, boosting began to be monitored during the Games in Sydney 200021. Between 2007 and 2009, the IPC used a questionnaire to investigate the practice of boosting in 93 high-level athletes, wheelchair users, in the class T6 or above. The results showed that almost $50 \%$ of these athletes believed that the practice is more or less dangerous, yet more than $16 \%$ had used the practice in competitions, and $79 \%$ had experienced spontaneous autonomic dysreflexia ${ }^{25}$.

The controversial world of sport as practiced by athletes with disabilities includes social, political, and ethical dilemmas, and, of course, health concerns. Maintaining good health is one of the central goals associated with the rehabilitation of the disabled individual. However, ironically, the cost may be the result of another aspect of vulnerability in the world of disability sports: secondary disabilities associated with sports injuries.

\section{Athletes have left their marks on Paralympic sports: But, at what cost?}

New performance records in Paralympic sports are increasingly and gradually gaining the attention of fans, at least during media coverage of the Games. Although the Paralympic cycle is four years, and even though Winter Paralympics is alternated-making a two-year gap between the Summer and Winter Games, the Summer Games have become the most prestigious. While national and international competitions do take place, athletes predominantly prepare their training seasons to meet this Paralympic event.

Training routines have conditioned athletes for high-performance sports, and to respond quickly to the demands of competition seasons, including opportunities to win medals, they push their physical limits in an intense regime of training $^{19}$. However, they also are more exposed to injuries and, consequently, to increased risk of suffering additional disability conditions, particularly from chronic injuries.

Survey13, administered in London in 2012, and which relates to the incidence of sports injuries in Paralympic athletes, is the most detailed study on the problem or sports injuries by the IPC, according to Webborn and Emery ${ }^{26}$. These authors summarize the findings: 3,565 athletes $(84 \%$ of the participating athletes) of 160 delegates (98\% of the countries' delegates of the games) responded to a questionnaire related to injuries that occurred during training and competition in 20 sports. The results showed that a total of 49,910 athletes per day were monitored globally. During the London Games, a total of 539 athletes suffered 633 injuries. The global injury rate was 12.7 injuries per 1,000 athletes. In the same study, the injury rate was similar among male and female athletes. Pre-Games injury rates in women were higher than during the competitions. Higher rates of injury were found in older athletes for sports such as football 5 (22.4 per 1,000 injuries). In general, 51.5\% of lesions were primary acute traumatic injuries. The most common injury (percentage of total injuries) occurred in the shoulder (17.7\%), followed by wrist/hand (11.4\%), elbow (8.8\%), and knee $(7.9 \%)$. The 2012 London/ IPC study identified major differences between sports, and it highlighted the need for longitudinal studies rather than those limited exclusively to a Paralympic season.

One of the earliest studies on incidence of injury in athletes with disabilities was conducted by Curtis and Dillon ${ }^{27}$. Of 128 wheelchair athletes interviewed, all reported suffering at least one injury since they began their sport. Some had accumulated as many as 14 injuries. A total of 93 athletes reported 291 injuries. 
The most common injuries involved soft tissues (33\%), bed sores (18\%), and skin lacerations (17\%). In these cases, many of the athletes never sought medical treatment.

As in the past, many athletes with disabilities come from limited economic conditions; others reside in countries that do not provide forms of treatment or prevention. Chronic problems arising from repeated injuries can lead to more serious consequences over time. For example, athletes who use wheelchairs may develop weakness and numbness in the hands, or carpal tunnel syndrome (CTS). Constant trauma and compression of the heel of the hand for each stroke in the act of pushing the wheelchair may reduce the functionality of the upper limbs and increase incidence of vertebral herniations. Obtaining appropriate diagnoses and treatment are not always feasible due to lack of resources and, sometimes, lack of recognition that there is a problem. The problem becomes more serious when it occurs in regions affected by disability, such as paralyzed areas that lack sensation.

Health education programs for preventing disabilities must be offered to disabled athletes, particularly to those who come from poorer regions or low socio-economic backgrounds. Athletes should be trained to inspect their bodies using various strategies, especially if they can't see injuries (blind athletes) or feel the affected area (paralyzed athletes). Athletes should be able to recognize the demands of their training protocols - through routine and constant performance assessments, and, therefore, know how to differentiate normal signs of fatigue from signals of a body damaged by exercise. Sports injuries that become a routine in the life of a disabled athlete can prematurely end his or her athletic career, and lead to the early retirement of elite athletes ${ }^{28}$.

\section{Does empowerment through disability sports preclude success in business?}

There is no question that elite (non-disabled) athletes who win and earn medals gain much popularity and financial opportunities - often making them millionaire sports figures. Sport is big business, producing billions of dollars in revenues. According to Forbes ${ }^{29}$, the sports industry in the North American market - driven by major professional leagues such as Major League Soccer, as well as by intercollegiate sports - is a growth industry. The industry, which produced $\$ 53.6$ billion in 2012 , is expected to produce $\$ 67.7$ billion in 2017, marking an annual growth rate of $4.8 \%$. Sport is a hugely profitable business, and athletes no longer play for fun. They now are paid professionals.

Olympic athletes, especially males, naturally attract private sector companies for sponsorships, investments, and to represent their brands. While such athletes typically reach celebrity status through their association with certain brands and transition into having long, successful careers, Paralympic athletes mostly attract the attention of charitable investors or of government funding. Media coverage typically grants visibility to disabled athletes only for the period in which their winning appears relevant, which commonly is tied to a particular Paralympic season. The Paralympic Games, the most important competition in the world for disabled athletes, occurs every four years. The news cycle for Paralympic athletes, therefore, allows some athletes simply to fall into anonymity for what could be considered a very long period of time for an athlete. Despite this, during the past two Games, some Paralympic athletes, Brazilian Alan Fonteles, for example, have gained notoriety, and have captured the attention of the media as well as of private investors. Currently, Fonteles earns a salary of 60,000 reais (+US\$ 17,000), according to Globo.com ${ }^{30}$. Yet, his earnings are astronomically less than the earnings of professional athletes like Anderson Varejão, who plays basketball in the NBA and earns $\$ 10$ million per year ${ }^{31}$. For elite athletes with disability, sport as a career and a means for living is highly unpredictable, and presents a very uncertain future.

In Brazil, for example, the lack of public and private sector funding for disability sports led to the creation of the Agnelo Piva Law, in $2001^{5}$. Two percent of federal lottery prize money is budgeted to the Brazilian Olympic Committee (85\%), and to the Brazilian Paralympic Committee (15\%). This incentive has allowed the Brazilian Paralympic Committee (CPB) to deploy new projects, one of which was the establishment of a permanent training team. Also, elite athletes began to receive scholarship incentives and prize money for each medal they win. Scholarships last for four years, typically until the next Paralympic event.

With a mission to "promote the universal access of disabled people to the practice of sports in its various levels," the CPB ${ }^{32}$ created a program for the development of new athletes in the school system, the Paralympic School Club. As a consequence, since 2006, the CPB annually organizes the School Paralympic games, designed for middle- and high school students throughout Brazil. In 2012, 1,200 athletes from 24 states gathered in the city of São Paulo to compete in one of the largest national games for students with disabilities ${ }^{33}$. For comparison, the most recent school games for non-disabled students (called Youth School Games, or "Jogos Escolares da Juventude"), founded in $1969^{34}$, had 3,000 participants.

Although government agencies have begun to invest in new young people with disability so that they may engage in sports, access to training and the professional quality of coaches and other sports professionals are limited. For the athletes already established in the national and international sport scenarios, coaches and sports professionals are from various backgrounds, often with only hands-on experience and quite often far removed from training methods based on science.

Additionally, the disability sports area is administered and led primarily by non-disabled people. With few funded positions, individuals committed to disability sports typically are volunteers for non-profit or government funded organizations $^{35,36}$. This structure and the volunteer function are not so common in the world of general sports, which are increasingly oriented toward financial profit. Also, athletes and sports professionals who have a disability rarely are employed to participate in or coach regular sports. The biased attitudes of non-disabled individuals toward professionals with disability tend to make them focus on limitations caused by the disability condition, not on competencies. Disability sports are generally conceived within the context of philanthropy, and people with disability, whether athletes or sports professionals, are expected to be "recipients of opportunities" granted by the non-disabled world. 
Indeed, individuals with disability historically have been dismissed from participating in decision-making policies, as well as having been ignored when voicing their choices in a variety of contexts (e.g., education, sports, family affairs, and work force, among others). James Charlton and his South-African colleagues, Michael Masutha and William Rowland ${ }^{37}$, began to advocate the need for scholars and international organizations to recognize a new paradigm that they termed, "Nothing about us without us." Their concerns about people with disabilities' invisibility and lack of power resulted in new policies that helped to increase the presence of peers with disability, who acted as liaisons during important decisions about disability issues, whether in sports, education, research, and for professional organizations. In 2004, United Nations Enable action adopted the theme, "Nothing about Us without Us," with the purpose of providing an opportunity for "active involvement and participation of persons with disabilities in the planning of strategies and policies that affect their lives." The United Nations Convention on the Rights of Persons with Disabilities, adopted by the United Nations General Assembly in December 2006, endorsed inclusive sports as a critical component of global disability rights.

Many individuals with disability gained respect, access, and became representative stakeholders in sports organizations, such as with Sir Philip Craven becoming the current president of the IPC executive board, and members at large such as Ann Cody, Duane Kale, John Petersson, and Todd Nicholson. In the United Kingdom, the English Federation of Disability Sports ${ }^{38}$ created the Inspire to Lead Project, alongside the Sports Leaders UK, Youth Sport Trust, and Sport England, to provide people with disability with leadership and volunteer opportunities. Since the Paralympic games, the Inspire to Lead Project has recruited and trained over 120 young disabled people to develop qualifications in sports leadership. The governing board of the EFDS also includes members with disability, such as Dr. Philip Friend, and Fran Williamson. Similarly, Disabled Sports USA includes members with disability on their board of directors, such as Executive Director Kirk Bauer and President Robert Meserve. The China Disabled Persons' Federation (CDPF), the official organization recognized by the IPC, has two chair members with disability, Mr. Li Zhijun and Mr. Liu Zaijun. Each has, respectively, visual impairment and hearing impairment ${ }^{39}$.

The Brazilian Paralympic Committee (CPB), in 2009 created the Counsel of Athletes, whose president, Ms. Simone Rocha, holds a chair on the Board of Directors to represent peer athletes' expectations and views about the activities of the Paralympic Movement. The counsel is formed by seven members, who are expected to come from various geographic regions in Brazil to advocate for diverse needs.

Media coverage (especially TV and social media) of the Paralympic games has helped to expand its exposure to audiences worldwide, educating them about a multitude of abilities in athletic performance, in many sports modalities. The games in London and Beijing were viewed by 3.8 billion people, according to IPC President Sir Philip Craven ${ }^{40}$. Such visibility helps to break stereotypes and challenge archaic, hegemonic social paradigms. Unfortunately, with regard to job opportunities in sports or in more general areas, professionals with disability have been underemployed; their personal perspectives about disability have not necessarily been considered an asset in their skill set. More recently, however, individuals with disability have become important contributors to sport organizations due to their ability to help with real-world strategic planning.

Breaking stereotypes is not an easy task for anyone. When it comes to disabled athletes' participation in a non-disabled world of sport, controversy often raises more restrictions than opens opportunities. For example, the eligibility of disabled athletes to participate in the Olympics can raise questions about the assistive and sport technology that athletes with disability rely on.

Mass media have only recently begun to give visibility to athletes with disabilities in the Olympic sport scenario. However, disabled athletes who have participated in the past in the Olympics have done so mostly in silence. In the 2012 London Olympics, the world looked at this phenomenon when Oscar Pistorius ${ }^{[5]}$ marked the history of the sport of track and field as the first bilateral amputee to compete with Olympic athletes. Yet, athletes with disabilities have participated in the Olympic Games since 1904 (Table 1).

Table 1. Athletes with disabilities who participated in the Olympic Games.

\begin{tabular}{ccccc}
\hline Year & Athlete & Disability condition & Modality & Result \\
\hline 1904 & George Eyser (USA) & One-leg amputee & Gymnastic & 3 Gold medals, 2 Silver and 1 Bronze \\
\hline $1928-1936$ & Olivér Halassy (Hungary) & One-leg amputee & Water polo & 2 Gold medals, 1 Silver \\
\hline 1952 & Lis Hartel (Denmk) & Polio & Women's equestrian & 1 Silver medal \\
\hline 1984 & Neroli Fairhall (New Zealand), & Paraplegia & Women's bow arrow & - \\
\hline 1996 & Paola Fantato (Italy) & Polio & Women's bow arrow & - \\
\hline $2004-2008$ & Marla Runyan (USA) & Legal blindness & Women's 1,500 m track & 8th place in the finals \\
\hline 2008 & Natalie du Toit (South Africa) & One-leg amputee & Swimming & $\begin{array}{c}\text { Qualified for the Olympic } \\
\text { Games in Beijing }\end{array}$ \\
\hline 2012 & Natalia Partyka (Polan) & One-hand/wirst amputee & Table tennis & $\begin{array}{c}\text { Qualified for the Olympic } \\
\text { Games in Beijing }\end{array}$ \\
\hline 2012 & Dong Hyun (South Corea) & Legal blindness & Bow arrow & $\begin{array}{c}\text { Record in 2012 and Bronze } \\
\text { medal for his team }\end{array}$ \\
\hline
\end{tabular}

Source: Wallechinsky and Loucky: http:/www.wired.com/2012/08/11-disabled-olympians/. 


\section{Leaving the sport competition scenario: a bleak future?}

Disability sport's history has been constructed by a few athletes who, themselves, had limited opportunities in their athletic careers. Athletes with disability became elite because of their and their families' personal investments. Disability sport provides individuals with a means to compete against oneself; to compete against one's own disability, against society's stereotypes. When individuals with disability become athletes, they develop new meaning through a new lifestyle. It is a lifestyle that increases chances for survival and, above all, provides a context for empowerment that comes from within. In actuality, they gain little from the sports marketplace. Therefore, these athletes rarely transition to retirement with societal or institutional support. Figure 6 depicts the implications of participating in disability sports on an athlete's life. The implications of leaving disability sport are well documented in the literature.

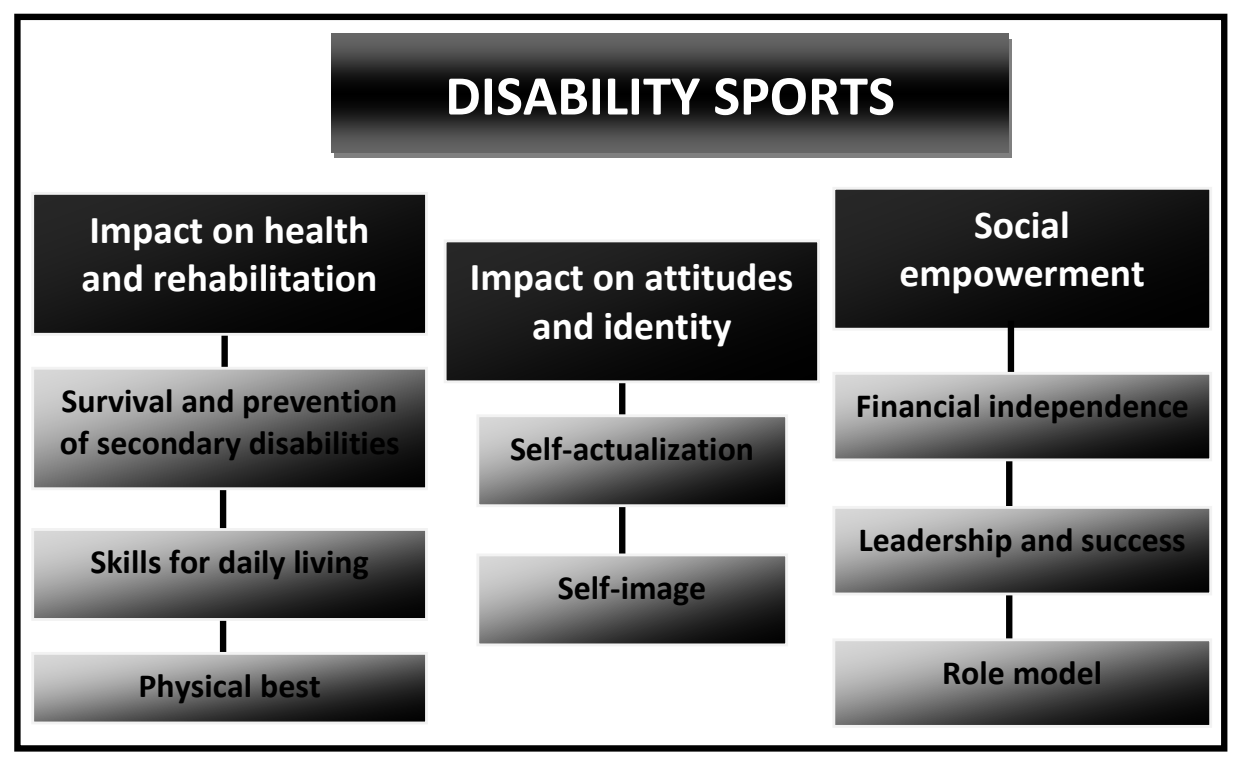

Figure 6. Implications of disability sports in an athlete's life.

Various societies worldwide provide financial support or disability pensions from health insurance agencies or from government agencies. Some athletes receive early retirement and, although the monetary amount is often below poverty standards, disabled people have free time. Time availability increases chances for sport commitments. However, many athletes come from modest families and rarely have the opportunity to become acquainted with international cultures. For some, sport participation can present such opportunities ${ }^{41}$.

Because sport participation often gives people with disability a new sense of life, athletes who leave the world of competition report feeling that they have lost something, beginning with leaving a circle of friends. They perceive that leaving the sport affects their physical competence, health, and their personal identity $^{42}$. However, disabled athletes typically have not made plans for the time when they will have to leave the sports world. Nor have their financial resources allowed them to make plans for the future.

In 2013, the Brazilian Paralympic Committee launched the program, "Heroes of disability sports" (i.e., "Heróis do Paradesporto" ${ }^{43}$. Nominated by the CPB and the Federal Lotteries, former athletes with disabilities who are now advocating for the Paralympic Movement receive a financial grant for 12 months (renewable). Recently Ádria Rocha Santos, Antônio Delfino, and Luiz Cláudio Pereira joined the program as ambassadors of the movement ${ }^{43}$. However, this is an important initiative, since there is no official program to guide or help athletes in retirement. Some examples of successful transition to retirement include swimmer Fabiana Sugimori, who attended four Paralympic Games, class S11 for the blind. She was sponsored by the Loterias Caixa throughout her career and became a tenured employee of the bank Caixa Econômica Federal. Swimmer Clodoaldo Silva is another example of financial success. His outstanding performance in the Athens Games in 2004, where he won six Gold medals, gave him notoriety and fame. Clodoaldo has several sources of income, thanks to his popularity. He is constantly invited to lecture and discuss his experiences as a disabled athlete ${ }^{44}$.

Although rare, the retirement of Olympic athletes can provide an opportunity for the application of knowledge to Paralympic sports. The Brazilian runner Joaquim Cruz, Gold medal winner of the $800 \mathrm{~m}$ track event during the 1984 Olympic Games in Los Angeles, is today one of the coaches of Paralympic athletes from the United States. In Brazil, the volleyball player Amauri, member of the generation Volleyball Silver in the 1980s, currently lends his expertise to the development of sitting volleyball ${ }^{45}$.

In an attempt to change this situation of uncertainty in the sporting careers of disabled athletes, in April 2015, the Ministry of Sports reactivated the National Commission of Athletes. The Commission is coordinated by former athletes Lars Grael (president), basketball player Hortência (vice president), and 
Anderson Lopes (secretary and representative of Paralympic athletics). The main issues of discussion include the athlete's career transition to retirement, support for former athletes in financial difficulty, and new guidelines on the Brazilian law of incentive to sport. Officially, this is the first time that issues of retirement of both Olympic and Paralympic athletes have been under the administration of the Ministry of Sports and the Olympic and Paralympic Committees ${ }^{46}$.

\section{Conclusions}

In 2016, Brazil will host the 15th Paralympic Games in Rio de Janeiro. The IPC president, Sir Philip Craven, expects that the Games will show the best performances by athletes in the history of sports for the disabled. Over 176 countries will compete in 23 sports in an attempt to break the 251 records set in London, in 2012. Again, we will witness the "power of the human spirit," according to Sir Philip ${ }^{47}$.

The Paralympic Movement of the IPC is perhaps one of the most effective human rights organizations due its ability to direct society's attention to critical issues related to disability and sports. The potential of sports for the disabled lies not just in its ability to provide audiences with spectacular events, but also as a means for improving human dignity and to help improve our understanding of the value of diversity. The consequences of the success of the Movement worldwide encompass areas of health and sport promotion, visibility of disability, the popularization of Paralympic sports, the scientific development of sport sciences in regard to athletes with disability, sports injuries, doping, sports periodization, physiological adaptation to exercise, the biomechanics of disability, and assistive technology, among others ${ }^{1,40}$.

Yet, today, the world of the Paralympic sport has been transformed from relative obscurity into a spectacle, thanks to the participation of exceptional athletes, to the technology of mass communication, and to changing views and the support of society. These sport "superstars" offer the "ordinary world" their unique visibility and new concepts of ability. While some of these heroes have already been celebrated, many future Brazilian athletes are still waiting for their opportunities. Young blind individuals, those in wheelchairs, amputees, or simply the uncoordinated, are spread throughout the cities and countryside of Brazil, and expect, above all, to play, run, swim, and take part in the international model of "sport for all." They expect sports opportunities to be a part of their daily lives, an option for rehabilitation, for the preservation of health, and a human right.

For the Paralympic athletes, sports define their identities, often damaged by pre-conceptions about the "perfect" or "efficient" body ${ }^{19}$. Sports provide a sense of competence and responsibility and, in the disabled world, become part of the history of a community. The sense of political responsibility that the sport environment offers to athletes also generates opportunities for becoming role models and for improving leadership skills. Leadership implies rigid adherence to the ethics and moral values of Olympism. Unfortunately, ethics and moral values often are corrupted by the same heroes who stumble over the temptation of a "medal at any cost."

As for government organizations and society, inclusion and accessibility have financial implications: the development of policies based on human rights. The realities of the athletes of the past inspire the achievements of the athletes of today. However, diversity in the meaning of athletic achievement-whether earning medals or breaking records - is not the only legacy for future generations. The meaning of success of the Paralympic movement, both locally and globally, should not be solely weighed in statistics about economic impact on host countries or on sport performance excellence. Instead, the success of the Paralympic Movement should be measured beyond the sports arenas, to where people with disability have been inspired to seek long-term quality of life through the practice of sports.

\section{Endnotes}

[1] According to DePauw and Gavron ${ }^{48}$, the term disability sports indicates sports that are designed for or specifically practiced by athletes with disabilities. Disabled World (2004) expanded this concept to include adaptive sports or parasports.

[2] Yeo et al. ${ }^{49}$, based on statistics from the 1980s, revealed that life expectancy after spinal cord injury still is $1 / 5$ of that of the general population. The years after World War II marked a period in which the majority of spinal cord injury victims died within the first two years of hospitalization due to sepsis and infections aggravated by prolonged immobilization. Survivors still showed high mortality rates: 4-5 times higher after the first and second decades from time of injury.

[3] The functional classification system is a system used to determine which categories of competition an athlete is likely to encounter adversaries with similar disability conditions. The system uses medical data of impairment and impairment on sport performance (i.e., sport specific). The sport classes include athletes that are equally challenged by a disability in order to make the competition a fair situation ${ }^{40}$.

[4] Among veteran Olympic athletes, Miraildes Maciel Mota, known as Formiga, is a Brazilian football player for the women's national football team, who participated five times in the Olympic Games (1996, 2000, 2004, 2008, and 2012). Volleyball player Hélia Rogério de Souza Pinto, known as Fofão, participated five times in the Olympics (1988, 1992, 1996, 2004, and 2008). The Brazilian athlete with the highest number of Olympic appearances was the sailor Torben Grael (1984, 1988, 1992, 1996, 2000, and 2004). Hugo Hoyama (table tennis), Rodrigo Pessoa (equestrian), Oscar (basketball), Robert Scheidt (sailors) are medalists who participated in five Olympic Games ${ }^{50,51}$.

[5] Oscar Pistorius, after being convicted of the murder of his girlfriend Reeva Steenkamp, in 2014, will not compete in any Paralympic Games for at least 5 years (length of sentence), according to The Guardian $^{52}$. However, his sports career is likely to end as, on 
December 3, 2015, South Africa's Court of Appeal in Bloemfontein overruled Judge Masipa's sentence of manslaughter and convicted Pistorius of murder. He will return to court to be sentenced again to a longer jail sentence ${ }^{53}$.

\section{References}

1. Blauwet C, Willick SE. The Paralympic Movement: Using Sports to Promote Health, Disability Rights, and Social Integration for Athletes with Disabilities. Physical Medicine Rehab. 2012; 4:851-856.

2. Gold JR, Gold MM. Access for all: The rise of the Paralympic Games. Journal of the Royal Society for the Promotion of Health 2007; 127(3), 137-141.

3. Steadward R. Integration and sport in the Paralympic movement. Sports Sci Rev. 1996; 5(1):26-41.

4. Mauerberg-deCastro E. Theory and practice in adapted physical education. The disability rights paradigm in synchrony with complex systems concepts. In. Ennis C. (ed.). Routledge Handbook of Physical Education Abingdon: Francis \& Taylor 2016; pp 201-222.

5. Mauerberg-deCastro E. Atividade Física Adaptada (Adapted Physical Activity). Ribeirão Preto: Novo Conceito, 2011.

6. UN World programme of action concerning disabled persons. 2010. Available from: http://www.un.org/disabilities/default. asp?id=23 (accessed on August 23, 2014).

7. Mushoriwa, T. A study of attitudes of primary school teachers in Harare towards the inclusion of blind children in regular classes. Brit J Special Education, 2001; 28: 142-147.

8. Wong DKP. Do contacts make a difference? The effects of mainstreaming on student attitudes towards people with disabilities. Res Develop Disabil. 2008; 29:70-82.

9. IPC. Strategic Plan 2015 to 2018. 2015. Available from: https://www.paralympic.org/sites/default/files/document/150619133600866_2015_06\%2BIPC\%2BStrategic\%2BPlan\%2B2015-2018_Digital.pdf, (accessed on May 5, 2016).

10. Medical College of Wisconsin. History of Physical Medicine and Rehabilitation. 2015. Available from: http://www.mcw.edu/ physicalmedicine/history.htm (accessed on June 6, 2015)

11. The Institute Guttmann. History. 2015. Available from: http:// www.guttmann.com/en/history (accessed on April 13, 2016).

12. IPC. IPC Governing Board approves first 16 sports to be included in the Tokyo 2020 Paralympic Games. 2014. Available from: https://www.paralympic.org/news/ipc-governing-board-approvesfirst-16-sports-be-included-tokyo-2020-paralympic-games (accessed on May 25, 2016)

13. IOC. Documents. Olympic Movement. 2016. Available from: http://www.olympic.org/documents-reports-studies-publications (accessed on May 25, 2016).

14. Hums MA, Moorman AM, Wolff EA. The Inclusion of the Paralympics in the Olympic and Amateur Sports Act: Legal and Policy Implications Governing Bodies for Integration of Athletes with Disabilities into the United States Olympic Committee and National. J Sport a Social Issues, 2003;27:261.

15. Laureus. Second Laureus Award for Paralympic great Daniel Dias. 2013. Available from: http://www.laureus.com/news/ second-laureus-award-paralympic-great-daniel-dias (accessed on May 6, 2015).

16. Williamson L. Sparks fly as blade stars go for Rio double after Oliveira steals the show with new world record at Olympic Stadium. MailOnline. 2013. Available from: http://www.dailymail.co.uk/sport/othersports/article-2380447/Alan-Oliveirasteals-new-world-record-Olympic-Stadium.html\#ixzz3dAI7JOHZ (accessed on May 7, 2015).

17. COB. Dados relevantes do Brasil em Jogos Olímpicos (Relevant data from Brazil in the Olympic Games). 2016. Available from: http://www.cob.org.br/pt/time-brasil/brasil-nos-jogos (accessed on April 6, 2016);

18. IPC. IPC Historical Results Database. 2015. Available from: https://www.paralympic.org/results/historical (accessed on May 5, 2016).

19. Brazuna MR, Mauerberg-deCastro E. A Trajetória do Atleta Portador de Deficiência Física no Esporte Adaptado de Rendimento. Uma Revisão da Literatura (The trajectory of the athlete with physical disability in the elite adapted sport. A review of the literature). Motriz J, 2001; 7(2):115-123.

20. Santamaria S, Mazzeo F. Ethical issues and doping in Olimpic and Paralympic Games. Sport Medicine Journal, no. 40, 2014. Available from: http://www.medicinasportiva.ro/SRoMS/english/ Journal/No.40/Ethical-issues-doping-Olimpic-ParalympicGames-full.html (accessed on June 12, 2015).

21. IPC. IPC Position Statement on autonomic Dysreflexia and Boosting, Section 2, Chapter 4.33, 2009. Available from: http://www.paralympic.org/sites/default/files/document/141113170443787_2014_10_13\%2BSec\%2Bii\%2Bchapter\%2B4_3_Position\%2BStatement\%2Bon\%2BAutonomic\%2BDysreflexia\%2Band\%2BBoosting.pdf 2009 (accessed on June 13, 2015).

22. IPC. Annual anti-doping statistics. 2015. Available from: https://www.paralympic.org/sites/default/files/document/140408122808010_2013_Annual\%2BStatistics\%2BAD_ Final.pdf (accessed on May 5, 2016).

23. Van de Vliet P. Antidoping in Paralympic Sport. Clin J Sport Medicine, 2012; 22 (1):21-25.

24. Pipe A, Ayotte C. Nutritional Supplements and Doping. Clin J Sport Medicine, 2012; 12:245-249.

25. Bhambhani Y, Mactavish J, Warren S, Thompson WR, Webborn A, Bressan E, et al. . Boosting in athletes with high-level spinal cord injury: knowledge, incidence and attitudes of athletes in Paralympic sport. Disability Rehab, 2010; 32 (26):2172-2190.

26. Webborn N, Emery C. Descriptive Epidemiology of Paralympic Sports Injuries. Paralympic Sports Medicine Sci, 2014; 6:S18-S22.

27. Curtis KA, Dillon DA. Survey of wheelchair athletic injuries: common patterns and prevention. Paraplegia 1985; 23:170-175.

28. Wheeler GD, Steadward RD, Legg D, Hutzler Y. Campbell E. Johnson A. Personal investment in disability sport careers: an international study. Adapted Physical Activity Quarterly 1999; 16(3):219-237

29. Forbes. "Thanks to media, sports industry growth is set to accelerate". 2013. Available from: http://www.forbes.com/ sites/tomvanriper/2013/11/13/thanks-to-mediasports-industry-growth-set-to-accelerate/ (accessed on November 13, 2013). 
30. Globo.com. Alan Fonteles. 2013. Available from: http://globoesporte.globo.com/atleta/alan-fonteles.html (accessed on November 13, 2014).

31. Veja. Varejão renova com Cleveland e receberá US\$ 30 milhões (Varejão renews contract with Cleveland and will receive \$ 30 million). 2014. Available from: http://veja.abril.com.br/noticia/ esporte/varejao-renova-com-cleveland-e-recebera-us-30-mi/ (accessed on June 11, 2015).

32. CPB. Paraolímpicos da Silva (Paralympics' Silva). 2015. Available from: http://www.cpb.org.br/paraolimpicos-da-silva/ (accessed on April 11, 2015).

33. CPB. Paralimpíadas escolares (School Paralympics) 2012. Available from: http:/www.cpb.org.br/categoria/paralimpiadas-escolares/ (accessed on June 6, 2013).

34. Brasil. Jogos Escolares da Juventude. Histórico (The Youth School Games). Ministério do Esporte. 2013. Available from: http://www. esporte.gov.br/ (accessed on June 6, 2013).

35. Alexiou H. Developing young disabled people through sports leadership and volunteering. English Federation of Disability Sport East Midlands. 2009.

36. Fitzgerald H, Lang M. A Review of the Literature on Volunteering, Disability and Sport. English Federation of Disability Sport (East Midlands), The Carnegie Research Institute, Leeds Metropolitan University. Leeds: Carnegie Hall, 2009.

37. Charlton JI. Nothing About Us Without Us: Disability Oppression and Empowerment. University of California Press. ISBN 0-520-22481-7 1998. Available from: http://books.google. com/books? id=ohqff8DBt9gC\&lpg=PA3\&pg=PA3\#v=onepage \&q\&f=false (accessed on June 22, 2010).

38. English Federation of Disability Sports (EFDS, 2012). Inspire to lead. Available from: http://www.efds.co.uk/resources/past_programmes/581_inspire_to_lead (accessed on April 11, 2016).

39. CDPF. China Disabled Persons' Federation (CDPF). 2016. Available from: http://www.cdpf.org.cn/englishold/ (accessed n April 6, 2016).

40. IPC. Classification. 2015. Available from: https://www.paralympic.org/classification (accessed on June 2, 2015).

41. Hopper CA. Socialization of wheelchair athletes in sports. Doctoral dissertation, University of Oregon, Eugene; 1984.

42. Wheeler G, Malone L, Van Vlack S, Nelson E, Steadward R. Retirement from Paralympic sport: A pilot study. Adapted Physical Activity Quarterly, 1996; 13(4): 382-399.

43. CPB. Ádria Santos e Antonio Delfino entram para a galeria dos Heróis do Paradesporto (Ádria Santos and Antonio Delfino enter the gallery of para-sports heroes). 2014. Available from: http:// www.cpb.org.br/adria-santos-e-antonio-delfino-entram-para-agaleria-dos-herois-do-paradesporto/ (accessed on June 14, 2015).

44. Lancenet. Líbero Fabi pede a criação de projeto para ajudar atletas aposentados (Libero Fabi calls for the creation of a project to help retired athletes). 2012. Available from: http:// www.lancenet.com.br/minuto/Libero-Fabi-criacao-atletasaposentados_0_773322855.html (accessed on June 14, 2015).

45. Brasil. Como os atletas paralímpicos buscam patrocínio e encerram a carreira (How Paralympic athletes seek sponsorship and make career transition) - Bloco 4. 2012. Available from: http://www2.camara.leg.br/camaranoticias/radio/materias/
REPORTAGEM-ESPECIAL/411061-COMO-OS-ATLETASPARALIMPICOS-BUSCAM-PATROCINIO-E-ENCERRAMA-CARREIRA.html (accessed on June 14, 2015)

46. Brasil. Logo após tomar posse, Comissão Nacional de Atletas promove primeira reunião (Soon after taking office, National Commission of athletes promotes first meeting). 2015. Available from: http://www.brasil2016.gov.br/pt-br/noticias/logo-apos-tomar-posse-comissao-nacional-de-atletas-promove-primeira-reuniao (accessed on June 14, 2015).

47. Rio 2016 Paralympic Games. IPC president predicts record-breaking performances at Rio 2016 Paralympic Games. 2016. Available from: https://www.rio2016.com/en/paralympics/news/ipcpresident-predicts-record-breaking-performances-at-rio-2016paralympic-games (accessed on June 2, 2016).

48. DePauw K, Gavron S. Disability Sport. 2nd ed. Champaign, IL: Human Kinetics, 2005.

49. Yeo JD, Walsh J, Rutkowski S, Soden R, Craven M, Middleton J. Mortality following spinal cord injury. Spinal Cord, 1998; 36: 329-33.

50. Torben Grael. Biography. nd. Available from: http://torben-grael. com/biography.php (Accessed on June 10, 2015).

51. Robertscheidt. O Robert é o maior atleta Olímpico individual do Brasil de todos os tempos (Robert is the most successful Olympic athlete of all time in Brazil). nd. Available from: http://www. robertscheidt.com.br/site_test.asp (Accessed on June 10, 2015).

52. The Guardian. Oscar Pistorius unlikely to run for South Africa again, says sports minister. 2014. Available from: http://www. theguardian.com/sport/2014/oct/23/oscar-pistorius-south-africa-sports-minister-reeva-steenkamp (accessed on June 1, 2015).

53. BBC News. Oscar Pistorius trial: 10 key moments. 2015. Available from: http://www.bbc.com/news/world-africa-29018522 (accessed on May 16, 2016).

\section{Corresponding author}

Eliane Mauerberg-deCastro Department of Physical Education. Laboratory of Action and Perception,

São Paulo State University

(Universidade Estadual Paulista)

Av. 24-A, 1515, Bela Vista

Zip code: $13506-900$

Rio Claro, SP, Brazi

Email: mauerber@rc.unesp.br

Manuscript received on March 22, 2016

Manuscript accepted on May 30, 2016

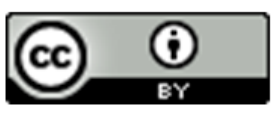

Motriz. The Journal of Physical Education. UNESP. Rio Claro, SP, Brazil - eISSN: 1980-6574 - under a Creative Commons license - Version 3.0 